\title{
Legal design and reporting harassment: preliminary considerations on the comparative efficacy of U.S. and Brazilian sexual harassment law
}

\author{
Estrutura legal e relatório sobre assédio: considerações \\ preliminares sobre a eficácia comparativa da \\ lei de assédio sexual dos EUA e do Brasil
}

\begin{abstract}
Augustus Bonner Cochran III
Ph. D. at the University of North Carolina, professor of the Social Politics Department at Agnes Scott College, Decatur, GA - USA, e-mail: gcochran@agnesscott.edu
\end{abstract}

\begin{abstract}
Laws against sexual harassment have been called "a feminist success story" (Zippel 2003). The creation of legal prohibitions against the historic and still widespread abuse of sexual harassment indeed represents a stirring story of innovation, both in the United States, where the problem was first dealt with as a legal matter, and now as a nearly universally recognized social problem. The effectiveness of these laws, however, remains a
\end{abstract}


contentious subject, especially the question of whether policies are shaped to realistically deal with the conduct of perpetrators and the way targets actually respond. The variations in national laws present an opportunity to compare and contrast the contours of different legal responses to this problem and perhaps identify policy designs that are most effective in combating this misconduct. To this end, this paper sketches the different legal prohibitions in place in the U.S. and Brazil and explores the likely counter-reactions that these policies might encourage in sexual harassment victims.

Keywords: Legal design. Reporting harassment. Sexual harassment. Law. EUA. Brazil.

\section{Resumo}

As leis contra o assédio sexual têm sido consideradas "uma história de sucesso feminista" (ZIPPEL, 2003). A criação de proibições legais contra o abuso histórico, e ainda muito presente, do assédio sexual de fato representa uma história de inovação, tanto nos Estados Unidos, onde o problema foi tratado como uma questão jurídica, como um problema social quase universalmente reconhecido como tal. A eficácia dessas leis, no entanto, permanece um assunto controverso, especialmente quanto ao questionamento sobre se as políticas são moldadas de forma realista, de modo a lidar com a conduta dos criminosos e da maneira como estes devem responder. As variações nas legislações nacionais apresentam uma oportunidade para comparar e contrastar os contornos de diferentes respostas legais para esse problema e, talvez, identificar projetos políticos que são mais eficazes no combate a essa conduta. Para esse fim, o artigo esboça alguns aspectos legais em vigor nos Estados Unidos da América e no Brasil, explorando as prováveis contrarreações que essas políticas possam acarretar no tocante às vítimas de assédio sexual.

Palavras-chave: Estrutura legal. Relatório sobre assédio. Legislação. Assédio sexual. EUA. Brasil.

\section{Introduction}

Numerous commentators have noted that with globalization of the economy, we are witnessing the diffusion of many policies and legal

Rev. Direito Econ. Socioambiental, Curitiba, v. 3, n. 2, p. 401-446, jul./dez. 2012 
norms. Increasing international interaction and the emergence of supranational institutions and transnational advocacy networks (ZIPPEL, 2004) present both pressures to standardize laws for the sake of regularizing norms as companies do business beyond national boundaries and employees migrate or work for transnational organizations (ORIHEULA; MONTJOY, 2000) as well as opportunities to coordinate and conform disparate laws through readily available information ${ }^{1}$. Some observers posit a convergence of legal norms; David S. Law (2008, p. 15-25, p. 79) surveys the varying forms convergence can take (as well as noting the possibility of non-convergence), arguing that competition for capital and skilled employees can potentially unleash a "race to the top" that elevates guarantees of civil rights and civil liberties. Koch (2003) even goes so far as to claim that a "global legal culture" is emerging, one that will blend aspects of civil law and common law systems.

Sexual harassment law would seem to represent a prototypical instance of diffusion. "[S]exual harassment has a long past but a short history” (GELFAND; FITZGERAL; DRASGOW, 1995). Although the longstanding practice of sexual harassment has been documented, the phenomenon was not explicitly recognized and named until 1975 in U.S. The "discovery" of sexual harassment spurred a campaign by feminists to legally prohibit sexual harassment as one tool to prevent it (BAKER, 2008). After a rocky start in the early litigation, the Catharine MacKinnoninspired strategy of challenging sexual harassment as discrimination against women bore fruit in the 1986 Meritor Savings Bank v. Vinson case when the U.S. Supreme Court interpreted Title VII of the 1964 Civil Rights Act as prohibiting sexual harassment as a form of sex discrimination (COCHRAN, 2004). In the ensuing two decades, other nations as

1 Information can represent pressure as well as opportunity. Britain is considering revisions to its libel law to bring it more into line with the United States' more defendant-friendly standards because of pressure from international groups and publishers whose publications are increasingly available to British readers on the internet and who fear damage awards to "libel tourists", foreign nationals who use British courts to sue for libel (PFANNER, E. A fight to protect americans from british libel law. New York Times, May 25, B3, 2009). 
well as supranational entities such as the European Union have proceeded to adopt legal bans on sexual harassment (ZIPPEL, 2003).

Yet the process of policy diffusion is not as straightforward as simple copying. One student of policy diffusion, Kurt Weyland (2005) has found temporal and spacial as well as substantive patterns to policy diffusion, which he explains largely by the cognitive heuristics of availability, representativeness, and anchoring, although recognizing other factors that encourage diffusion: external pressures, normative imitation, and rational learning. Although Weyland finds mainly substantive similarities among policies diffused cross-nationally, even in dissimilar settings (WEYLAND, 2005, p. 4), other authors emphasize the importance of local factors in interacting with and resisting the homogenizing effects of globalization (Ong; Feng $\mathrm{Xu}$ ), thereby producing more singular local variations in policies.

For a fundamental gender relations issue such as sexual harassment, cultural differences seem especially likely to engender significant heterogeneity in policy approaches. Some authors have developed schemes and indices for measuring and classifying cultural differences relevant for understanding different behaviors and understandings of sexual harassment in various cultures (HOFSTEDE, 1991; FIEDLER; BLANCO, 2006). Not surprisingly, empirical studies indeed find cultural differences in understanding and reacting to sexual harassment (GEFLAND; FITZGERALD; DRASGOW, 1995; MERKIN, 2008; SOUZA; PRYOR, 1998), although Gefland, Fitzgerald, and Drasgow argue that their sexual experiences questionnaire (167) conceptualizing three dimensions of sexual harassment (gender harassment, unwanted sexual attention, and sexual coercion (168) can validly measure sexually harassing behavior cross-culturally. Not merely at the individual cognitive level, studies find macro-cultural variations in understanding sexual harassment. For example, mass media in France have tended to sensationalize the issue, highlighting the most outrageous cases and largest settlements and portraying anti-sexual harassment measures as "the American disease" (i.e., as a residue of Puritanism) (SAGUAY, 2003). 
Besides culture variations, national legal systems exhibit significant divergences, not least the basic divide between civil and common law systems (Merryman). Bourdieu (1987, p. 1) introduces the concept of the "juridical field": "an area of structured, socially patterned activity or 'practice,' in this case disciplinarily and professionally defined". Supplementing formal structures and texts, these informal and often implicit cultures, codes, and "doxa" $(4,5)$ can often lead to "induced misunderstanding" while exerting "invisible pulls" not unlike the effect of a magnet. Besides implying that juridical fields are sites of "struggle for conceptual control" at the intersection of sociological and juridical interactions (6), this emphasis on the autonomous professional self-structuring of the juridical field implies that global influences will be refracted through the magnetic force-fields of national legal systems.

Comparative studies of sexual harassment law encounter diverse approaches to the problem in different countries, with similar social experiences leading to disparate policy responses (BAER, 2003). France, for example, has pursued a path starkly divergent from the U.S. in its approach to the problem of sexual harassment. Saguay stresses culture and the influence of mass media to explain stark difference in the way U.S. treats sexual harassment as sex discrimination contrasted to its criminalization in French law. While in the U.S. law sexual harassment is broadly defined to include hostile work environments as well as quid pro quo intimidation (MERITOR SAVINGS BANK, 1986), in France, sexual harassment is narrowly defined as an abuse of hierarchical power to obtain sexual favors by coercion (that is, a species of quid pro quo). The offense, conceived of as an assault on personal dignity and sexual liberty, is treated as a crime, punishable by a fine of up to and as prison sentence as long as 2 years. This conception of sexual harassment, Saguay argues, reflects France's historical concern with class relations, de-emphasizing the specifically gendered nature of the abuse. This particular understanding comports with the country's cultural self-image as appreciating sex as well as the widely shared judgment that sexual harassment is largely an American invention that reflects its Puritanical legacy in supposedly 
seeking to ban all eroticism from the workplace. Finally, Saguay concludes that this view of sexual harassment is sustained by the French media, who sensationalize the issue by largely portraying it as a foreign, mainly American, hang-up by trivializing conduct defined as harassment and exaggerating awards received by victims. The emergent concept of moral harm, popularized by the writings of Marie-France Hirigoyen, nonetheless presents a starkly different diagnosis of harassment, including sexual harassment, as an offense against personal dignity and thus founded on European instead of U.S. legal and philosophical bases. Defined as "all abusive conduct, notably manifesting itself by behavior, words, deeds, gestures, or writing, that can harm the personality or physical integrity of the person, put their employment in jeopardy, or degrade the work climate" (SAGUAY, 2003, p. 146), prohibition of moral harm is designed to regulate personal conflict between individuals or groups, ungrounded in any analysis of power dynamics or the potential structural sources of the conflict. Despite its abstract nature, however, it offers yet another tool to fight sexual harassment with the potential to expand anti-sexual harassment policy into the civil realm and to include a broader array of offenses, such as the types of conduct that create hostile working environments.

Baer (2003, p. 593) argues that different fundamental values underlie policy approaches in the United States on the one hand and the European Union and Germany on the other. U.S. law characterizes sexual harassment as a violation of equality, while the European prohibition views sexual harassment as an infringement of dignity, which Baer argues is a species of liberty. She criticizes the dignity-based approach as individualizing behavior and conceptualizing humans as autonomous subjects without taking sufficient account of social hierarchies and ignoring the function of sexuality in gender discrimination, leading law to privilege the perpetrator's rather than victim's perspective. She concludes, however, that neither the equality-based or dignity-based approach is adequate as long as equality and liberty are conceived as conflicting rather than reinforcing values. Zippel (2003, p. 176-178) also compares U.S. and German sexual harassment law, characterizing the former as individualistic and 
the latter as collectivist, differences reflecting not only culture but also legal institutions and cultures, industrial relations systems, institutionalized gender equality politics, and types of welfare states (liberal vs. corporatist). The individual model conceives of sexual harassment as a conflict between perpetrators and victims, viewed as individual actors, and it aims to protect the rights of individual employees through instituting formal policies and procedures for resolving conflicts between perpetrators and victims, stressing training in rights and unacceptable behaviors and confrontational strategies relying on formal complaints, even lawsuits. The collectivist model is aimed against sexual harassment as a form of "mobbing", a type of conflict between work colleagues or superiors and employees which attacks the victim as inferior. Mobbing then is "a situation in which one or more persons systematically and over a long time period, attack someone directly or indirectly with the goal of marginalizing and driving them out" (ZIPPEL, 2003, p. 188). The more collectivist German approach the seeks to uses group-based, often volunteer and corporatist, interventions to enhance group interests and protection, using informal complaints, consultation, and group, power-sensitive, and team-based dynamics to reform workplace cultures (ZIPPEL, 2003, p. 177-180).

Latin America seems to hew closer to the European rather than the North American model ${ }^{2}$. In Peru, for example, the first response dating from the 1990s was to deal with sexual harassment as a criminal matter, a "misdemeanor against "public honor" closely aligned with sexual assault (actionable only if coerced sexual intercourse is actually completed). In the civil realm, sexual harassment victims may be able to seek redress under the broader rubric of "moral wrong" (dano moral), the concept pioneered

\footnotetext{
2 This pattern may represent at least a partial refutation of Weyland's (WEYLAND, K. Theories of policy diffusion: lessons from Latin American pension reform. World Politics, v. 57, n. 2, p. 262$295,2005)$ geographical clustering hypothesis that "[i]n special terms, diffusion tends to have a clear geographic concentration, spreading first throught the region in which the innovation was designed and only later reaching other areas of the world". Perhaps cultural proximity outweighs geographical proximity in explaining the diffusion of a policy such as sexual harassment, infused as it is with cultural values.
} 
in France that allows plaintiffs limited monetary recovery under a theory of "civil responsibility". A labor regulation is the first Peruvian law to address sexual harassment directly, but the procedural prerequisites are severe (six days notice to the employer and resignation (sic) before filing suit) and recovery is limited (severance pay limited to one year's salary) (ORIHUELA; MONTJOY, 2000, p. 330-332). India takes a more communal approach to extirpating sexual harassment, relying to a great degree on grass roots self-help measures (NUSSBAUM, 2004). On the other hand, Japan appears to have followed a path closer to the U.S. trajectory, with the anti-sexual harassment agenda having been set by a landmark Supreme Court decision in 1992, followed by equal employment opportunity regulations that prohibit sexual harassment (although inadequately, since the scope of the ban applies only to the workplace, defined narrowly to exclude the frequent cultural practice of obligatory though not formally required business social functions). Torts suits provide only weak protection in Japan, because monetary awards are restricted, excluding punitive damages, and because of courts' tendencies to deny that plaintiffs were "real victims" because they failed to act in the manner courts suppose a reasonable victim should (TSUNODA, 2004).

Israeli sexual harassment law may represent the most straightforward instance of the influence of U.S. law, although it scarcely constitutes a case of diffusion by simple copying. Recognizing the limitations of a 1988 criminal prohibition of sexual harassment in the workplace and elsewhere, feminist scholars analyzed the U.S. legal experience, its drawbacks as well as its achievements, for lessons for reforms: that combating sexual harassment required specific legislation, not merely court rulings, banning sexual harassment everywhere, not merely in the workplace; that the harm of sexual harassment had to be conceived as broader than a violation of equality; that law should not attempt to distinguish between quid pro quo and hostile environment harassment; and that the law should adopt a "reasonable creature" standard (KAMIR, 2004, p. 566-577). A 1998 statute declared sexual harassment an offense against equality and dignity, defined a variety of behaviors as sexual harassment 
as civil wrongs and authorized punitive damages, though severely limited in amount. In addition to holding perpetrators personally liable, it created employer responsibility for sexual harassment that occurs in the workplace and requires employers to take effective measures to prevent and remedy sexual harassment.

International and supranational organizations have recently added a human rights basis to the battle against sexual harassment. Although conditions that permit this abuse share commonality across a wide range of settings, cultural variations and different priorities, such as the need for economic development, can create pressures to refract universal standards to fit local particularities (CHINKIN, 2003). In addition, international norms originate from multiple source, resulting in uncoordinated approaches to the problem. Some international norms, such as International Labor Organization Conventions, treat sexual harassment as violative of equality, while other international instruments, such as the Inter-American Convention on the Prevention, Punishment, and Eradication of Violence Against Women prohibit sexual harassment as a form of violence and offense against dignitary and other rights.

These diverse approaches to combating sexual harassment have led to debates concerning the most valid philosophical foundations assumed by different measures, in particular contention over whether equality or liberty provides a firmer basis for laws against sexual harassment. Some feminist law scholars criticize the reliance on personal integrity and dignity as individualizing the problem and ignoring the systemic gender inequalities that underlie particular cases (ZIPPEL, 2004, p. 61). Baer (2004, p. 583) acknowledges that dignity, founded upon deep liberal concerns for liberty, personhood, integrity, and respect, but argues that this approach tends to be gender blind, conceiving of humans as autonomous rather than embedded in social hierarchies, especially in the workplace, and that it ignores the role of sexuality in gender discrimination (BAER, 2004, p. 593). Without taking more explicit notice of the social context, specifically structural gender inequality and the unique harm done to women by sexual harassment, the dignity approach is prone to adopt a perpetrator's 
perspective on the problem. On the other hand, European feminists (and non-feminists) have deplored American "excesses" in defining sexual harassment too broadly and in focusing too exclusively on the sexual aspects of discrimination (ZIPPEL, 2004, p. 61). U.S. law professor Vicki Schultz (1998) has likewise argued that in overemphasizing sex discrimination, policies are both overbroad (sweeping in conduct that is sexual but not discriminatory) and underinclusive (missing behavior that discriminates on the basis of gender but that does not involve sex. Kamir (2004, p. 565) criticizes the way the discrimination approach is actually implemented as based on Aristotelian notions of equality as sameness, rendering this view also blind to the systemic inequality of women revealed by MacKinnon's dominance theory of inequality. Of course, the equality and dignity approaches are not necessarily conflictive; Baer (2004, p. 595) recommends a "scheme of interrelatedness" in which "equality is an asymmetrical, substantive right against in this case sexualized hierarchies, and dignity is the nominative point of reference which guarantees equal respect for every individual". Kamir (2004, p. 568) suggests that the approaches should be complementary rather than competing:

sexual harassment discriminates against women by not respecting them as women and as human beings, by violating their dignity, and by restricting their liberty to determine themselves and to lead lives free of fear and restriction. It disrespects women and violates their dignity by mirroring and perpetuating a social reality that does not treat them as equal.

As Zippel (2003, p. 186-190) notes, the individualistic model is compatible with managerial values of risk minimization, productivity and efficiency, but the collectivist model is likewise consonant with contemporary management theories stressing work restructuring to promote teamwork and flattened hierarchies. Given that neither approach challenges the hidden hierarchies or gendered division of labor obscured by the emerging post-Fordist, flexible production regime of accumulation, perhaps her suggestion of a third approach that explicitly recognizes and 
aims against gendered structures of inequality would indeed be the ideal model (ZIPPEL, 2003, p. 194).

Different national approaches to legal prohibitions on sexual harassment raise not only interesting empirical questions about interactions between the global and the local and the cultural and juridical (ZIPPEL, 2003, p. 176), but the variation also presents potential opportunities to improve the effectiveness of anti-sexual harassment policy, including the intriguing possibility that some regulatory approaches might prove more effective in preventing and curing sexual harassment as well as the potential for all policies to benefit from dialogue among approaches. Zippel (2004) documents how the interactions among levels of national and supranational governments in the European Union has created not merely a boomerang effect of policy reshaping but that the dynamic and continuing iterations among these levels of governance has produced a ping pong effect as the issue is repeated revisited in the complex, multi-leveled policy process. Focusing more on cross-national influences, Bernstein (1997) traces the mutual influences exerted by U.S. and European approaches to the issue of sexual harassment, arguing that this pluralistic rather than unidirectional set of interactions can lead to comparing and borrowing that would be beneficial to the laws of all nations involved. Thus, a careful assessment of diverse legal approaches could provide empirical evidence for institutional and policy design issues and perhaps even establish a sounder basis for "rational learning" (WEYLAND, 2005) to promote a more intentional approach to policy adoption and diffusion based on dialogue and reciprocally informed choices.

In this vein of "comparative-law synthesis" (BERNSTEIN, 1997, p. 1234), this paper begins a project intended to compare the legal prohibitions of sexual harassment in the U.S. and Brazil with the hope of assessing their strengths and weaknesses and providing a firmer basis for mutual "learning" from these countries' varied experiences. The second part of the paper will examine sexual harassment law in U.S., its dramatic development and subtler retrenchment, and consider how a developing gap, "law vs. reality", may hamper an effective rights claiming regime. 
Part III sketches Brazilian sexual harassment law, its development in penal law and subtle migration into employment law. These policies are situated in the broader context of the Brazilian legal system and more specifically its employment law system (Justiça do Trabalho) as a rights claiming regime. Part IV poses some hypotheses concerning possible different efficacies of U.S. and. Brazilian sexual harassment rights claiming regimes based on a) cultural differences, and b) differences in juridical fields and surveys studies comparing sexual harassment in U.S. and Brazil. Part V outlines future research strategies to disentangle various factors accounting for national differences and to test hypotheses about U.S.-Brazilian divergences. The conclusion will raise questions and preliminary reflections about relative efficacy of U.S. and Brazilian approaches.

\section{Sexual harassment law in U.S.}

An intriguing backdrop to the discussion of sexual harassment law is the now venerable debate on role of law in social change. Can law be used to change society in order to cure social ills, or do laws merely reflect the values and distribution of power of the social status quo, with legal changes merely signaling that social change is already afoot? This topic is hotly contested in assessments of the role of courts and law in the U.S. civil rights movement. Although the Supreme Court's Brown v. Board of Education (1954) decision is widely reputed to have delivered the death knell to Jim Crow segregation, the law announced from bench has been criticized as ultimately not effective (Rosenberg). To cite a Brazilian example, employment law, codified in the Consolidação das Leis do Trabalho (CLT) (1943, p. 41) bestows a bevy of employee rights; historian John French notes that if Brazilian employees actually enjoyed anything approximating the rights enshrined in the law books, Brazil would be the best place on earth to work, a veritable workers' paradise. But reality falls far short from the idyllic scene depicted in law library shelves. As French describes it, Brazilian workers are "drowning in laws, but starving 
for justice". Yet French does not judge this law as completely illusory. He finds material effects of legal reforms on the distribution of resources, material and ideological, on workers' legal consciousness, on the labor movement, and on potential redistributions of social power. His criterion for genuine reform is whether the policy opens space for autonomous self-organization for employees, and by this measure, sees at least partial success in the CLT. Likewise, sociologist Michael McCann (1994), based on research into the comparative worth movement in the U.S., is more sanguine about the possible potency for law in supporting change, although he concludes that law can only play an auxiliary role to active social movements in changing society. Against this deeper theoretical controversy over the role of law in reform, the historical evolution of sexual harassment law demonstrates progressive potential but also highlights limits to law as instrument of social change.

Sexual harassment was not recognized as a social problem until 1975, when a group of feminists at Cornell University invented the term to denote the common experiences of working women unearthed when discussing problems at work (BAKER, 2008). Determined to use the law to combat what they viewed as a barrier to women's economic prospects, feminist strategists, following the pioneering legal brief authored by Catharine MacKinnon (1979), settled on claiming that sexual harassment constituted a violation of the Civil Rights Act's Title VII, its equal employment opportunity provision. Despite early setbacks in lower courts that persisted in viewing sexual harassment as an interpersonal wrong, feminists won a victory in Meritor Savings Bank FSB v. Vinson (1986) when the Supreme Court, interpreted Title VII broadly to include sexual harassment in its prohibition on sex discrimination. Further, the Court recognized that creation of a hostile environment as well as quid pro quo coercive sex was prohibited under the law, adopting the Equal Employment Opportunity Commission's definition of sexual harassment as

unwelcome sexual advances, requests for sexual favors, and other verbal or physical conduct of a sexual nature constitute sexual harassment 
when (1) submission to such conduct is made either explicitly or implicitly a term or condition of an individual's employment, (2) submission to or rejection of such conduct by an individual is used as the basis for employment decisions affecting such individual, or (3) such conduct has the purpose or effect of unreasonably interfering with an individual's work performance or creating an intimidating, hostile, or offensive working environment (BERNSTEIN, 1994, p. 38).

The decision, however, contained elements that potentially limited the sweep of its ruling. The Court rejected the defense claim that involuntariness (apparently meaning explicit coercion) was required to establish illegal sexual harassment (the plaintiff in Meritor Bank had allegedly sleep with her supervisor, but she claimed she feared that resisting would jeopardize her job). Instead, the Court held that the test for determining whether sexual conduct constitutes illegal harassment is "whether respondent by her conduct indicated that the alleged sexual advances were unwelcome, not whether her actual participation in sexual intercourse was voluntary" (MERITOR BANK, 1986). This standard, however, put the burden of proving unwelcomeness on victims, rather than requiring perpetrators to prove that they reasonably perceived their conduct to be welcome. The Court responded to concerns that minor infractions could flood courts with litigation by sensitive plaintiffs by mandating that offending conduct must be "severe or pervasive". In a holding that exposed plaintiffs to the embarrassment of having their conduct put on trial by refusing to rule that evidence of plaintiff dress and sexual fantasies was inadmissible. The biggest disappointment of the Meritor decision, however, was that the Court declined to impose absolute vicarious liability on employers for sexual harassment practiced by their supervisors. Ruling out the opposite extreme as well by not exempting employers from liability just because victims failed to use company procedures to report harassment, the Court assumed the somewhat enigmatic middle position by admonishing lower courts to "look to agency principles for guidance" when deciding employer liability (MERITOR BANK, 1986; COCHRAN, 2004, p. 114-117). 
Meritor Bank is a prototypical illustration of policy-making in a common law system. In the absence of any legislated stricture against sexual harassment, lower courts began to consider legal interpretations of statutes that would encompass a prohibition on such conduct, with the Supreme Court eventually settling the matter by endorsing an innovative way of legally addressing this social problem. Meritor Bank then, like the Brown school desegregation case, demonstrates the potential of judgemade law to offer progressive cures for social ills. Yet the decision also illustrates some of the drawbacks of courts as policy-makers. Many issues were decided in a status quo affirming manner, or were simply left ambiguously open, necessitating long years of litigation in lower courts and several return visits to the Supreme Court for clarification. For example, the admissibility of dress and sexual fantasy evidence and the requirement that victims prove that conduct is unwelcome can shift the focus of a trial to the victim's conduct, perpetuating traditional sex roles and stereotypes. The requirement that harassment be severe or pervasive occasions much disagreement over the necessary level of harassment to sustain litigation, despite the Supreme Court's effort to clarify the standard in Harris v. Forklift Systems (1993). In that case, the Court announced a test with both objective and subjective elements:

conduct that is not severe or pervasive enough to create an objectively hostile or abusive work environment - an environment that a reasonable persona would find hostile or abusive - is beyond Title VII's Purview. Likewise, if the victim does not subjectively perceive the environment to be abusive, the conduct has not actually altered the condition of the victim's employment, and there is no Title VII violation.

The Court suggested that this judgment must be made in light of "all the circumstances" of the situation and identified some aspects of the harassing conduct to be examined in determining if it is sufficiently severe or pervasive to be illegal. "Reasonableness" in making these judgments has itself been questioned, in particular whether the appropriate perspective ought not to be that of a reasonable woman, as the Ninth Circuit held 
in Ellison v. Brady (1991), rather than that of a reasonable person, as the Supreme Court seemed to endorse in Harris (1993). Oncale v. Sundowner Offshore Services, Inc. (1998), without explicitly addressing the controversy, the Court seemed to opt for a compromise standard, the perspective of a reasonable victim, referring to "conduct which a reasonable person in the plaintiff's position would find severely hostile or abusive". Despite these reiterated efforts at clarification, many judges still dismiss sexual harassment suits at the summary judgment stage, claiming that plaintiff's allegations are not sufficiently serious to meet the requisite elements defining illegal harassment. Besides leaving many issues open and subject to constant litigation and revision, case-by-case adjudication has delayed and limited the extension of legal regulation to other areas, e.g., education.

Employer liability, however, remained the most perplexing open question after Vinson. Although courts generally held employers vicariously liable for quid pro quo harassment while requiring proof of employer negligence before imposing liability for hostile environment created by coworkers, it was not until 1998 that the Supreme Court attempted to settle issue the gray areas of quid pro quo when threats were unfulfilled or of hostile environments created by supervisors. In a duo of cases, Burlington Industries v. Ellerth and Faragher v. City of Boca Raton, the Court imposed vicarious liability on employers when harassment is accompanied by a "tangible employment action", defined as "a significant change in employment status, such as hiring, firing, failing to promote, reassignment with significantly different responsibilities, or a decision causing significant change in benefits. When there is no tangible employment action, however, employers are still subject to liability unless they can bear the burden of proving a two-pronged affirmative defense "that the employer exercised reasonable care to prevent and correct promptly any sexually harassing behavior", and "that the plaintiff employee unreasonably failed to take advantage of any preventative or corrective opportunities provided by the employer or to avoid harm otherwise".

The Faragher/Ellerth affirmative defense seems to place the burden on employer and to encourage pro-active prevention of sexual, 
and indeed, many companies have moved to adopt anti-sexual harassment policies and procedures in the wake of these decisions. Preliminary studies of lower courts, however, find that in practice judges shift the focus from the harassment by employers' agents to victims' responses. Too often courts, assume that if employers have policies in place, they have acted reasonably, in effect providing a safe harbor to employers with even superficial policies. Courts have also proved to be willing to presume that employer training is effective, though many employees consider these efforts token or a travesty ${ }^{3}$. These courts then subtly shift the burden to victims to prove that they acted reasonably, dismissing their claims if they failed to avail themselves of employers' procedures, however inadequate. In effect, this changes the standard from strict liability with an affirmative defense to a negligence standard: employers are only held liable if the knew or should have known about the harassment and failed to prevent or cure it.

The problem with the design of these legal rules as they have evolved over a couple of decades is that they appear to be squarely at odds with social realities. Although systematic statistics are woefully lacking, estimates are that up to $90 \%$ or $95 \%$ of sexual harassment targets do not report the abuse to their employers (COCHRAN, 2004, p. 186; ZIPPEL, 2003 , p. 184) ${ }^{4}$. Filing lawsuits is even less frequent; even among those who file formal charges with the with EEOC, a bare $1 \%$ proceed with lawsuits (BEINER, 2000, p. 57). If the law's protection is limited to those who respond immediately by using formal channels, then the law appears to be on a collision course with reality. The legal retrenchments are not limited

3 One study found that, contrary to expectations and intent, training actually reduced the probability that targets would confront their harassers and enhanced intentions to avoid conflict rather than reporting harassers. GOLDBERG, C. B. The impact of training and conflict avoidance on responses to sexual harassment. Psychology of Women Quarterly, v. 31, p. 62-72, 2007. Suggests that the explanation is that the training in this instance included information on the negative consequences for targets who assert their rights.

${ }^{4}$ Contrary to "common sense" and popular stereotype, men may be even less like to complain about sexual harassment than women. One survey found that only $7.8 \%$ of men experiencing same-sex harassment and $3 \%$ of men harassed by women took formal action (COCHRAN, 2004, p. 187). 
to implicit interpretations of burdens of proof. Important details of the "rights-claiming system" are evolving to make it more difficult for victims to avail themselves of rights and remedies provided by law" (BRAKE, 2008; GROSSMAN, 2000). Rules governing rights-claiming on both the front-end (making claims) of the "naming, blaming, and claiming" process and the back-end (protection against retaliation against claimants) are being weakened.

Up front, the statute of limitations period is short in Title VII cases: a complaint must be filed with the Equal Employment Opportunity Commission (EEOC) within 180 days (or 300 if a file goes first to a state agency) after the alleged violation occurred. Although modeled on the National Labor Relations Act, in those cases an experienced institutional actor, a union, is generally involved. Other similar statutes generally have either no statute of limitations or longer periods in which to file complaints (BRAKE; GROSSMAN, 2008, p. 866-869). The Supreme Court has also severely narrowed what counts as violations triggering the limitations period, rejecting the earlier continuing violations doctrine that permitted a pattern of discrimination to be actionable as long as one act occurred during the 180-day period. First the Court required that for discrete acts, "the limitations period begins anew with the occurrence of each act of discrimination" (BRAKE; GROSSMAN, 2008, p. 870). Then, in Ledbetter v. Goodyear Tire \& Rubber Co. (2007), the Court applied this rule to discriminatory pay, holding that the violation that triggered the statute of limitations was the original decision to pay less ${ }^{5}$. Requirements imposed by courts for reporting sexual harassment using internal company procedures, although not legally spelled out, are even more strictly limited. Delays in reporting found "unreasonable" under the Ellerth/Faragher standards include three months, 17 days, and even one week. Reporting to the wrong person, complaining to a union or the EEOC, failing to provide adequate information or non-cooperation with an investigation, can also be deemed failures to reasonably avail oneself

5 The first bill passed and signed in the new Obama administration overturned this Supreme Court decision. 
of procedures provided by employers. The courts have proved skeptical of excuses for failure to avail, rejecting a "generalized fear of retaliation" in favor of "specific credible threats" or tangible evidence of the employer's prior unresponsiveness to harassment complaints". Courts have even begun to apply the affirmative defense to cases of hostile environment by coworkers, requiring victims to demonstrate reasonable efforts to avoid harassment instead of holding negligent employers (who knew or should have known of harassment and failed to prevent or cure) liable. Finally, courts, following the lead of the Supreme Court in several significant arbitration cases, have given increased weight to private internal dispute resolution. For example, pursuit of such private mediation/arbitration procedures, which may be mandatory for employment, may supplant a right to sue for violations of statutory rights in a public forum or may run out the statute of limitations. Although made in reference to the trend in arbitration jurisprudence, the statement by Katherine van Wezel Stone (1996, p. 1050) might apply to the totality of our increasingly diluted rights-claiming system: "the result is a bitter irony for the worker - she has more rights and less protection than ever"6.

While strengthening requirements for reporting, on the back end, the Supreme Court has weakened victims' protections against retaliation when they do report. In Burlington Northern \& Santa Fe Railway Co. v. White (2006) the Court limited the definition of illegal retaliation to employer actions that are "materially adverse", meaning those that "might well have dissuaded a reasonable worker from making or supporting a charge of discrimination" (BRAKE; GROSSMAN, 2008, p. 908). Although protective on the surface, courts are tending to limit protections by assuming that reasonable workers are "resilient, self-sufficient, and willing to risk the loss of congenial relationships at work in exchange

6 BROWN, W. The most we can hope for. Human rights and the politics of fatalism. South Atlantic Quarterly, v. 103 , n. 2/3, p. 459, 2004. Has reached a similar conclusion about human rights, another area of law where abstract rights are strong but concrete enforcement mechanisms are lacking: "Americans have never had so many rights [...] and so little power to shape collective justice and national aims". 
for the assertion of civil rights". Another requirement imposed by the Court for protection from retaliation is that the complainants must have legally sound bases for believing that they rights were violated. Yet in a system where standards for defining illegal sexual harassment are murky, ambiguous, and constantly evolving, this requirement can leave complainants exposed to retaliation if they err on arcane legal judgments. For example, timing the reporting of harassment can be tricky, leaving victims to walk a tightrope between reporting too late, and losing their legal protection for failure to avail reasonably of company procedures, and reporting too early, thereby losing protection from retaliation if the harassment has not yet risen to a sufficiently severe or pervasive level to be deemed illegal.

Why don't targets simply report the harassment? The issue is complex, and social scientific studies supply only partial, tentative answers, but at a minimum, a range of factors must be taken into consideration. In the first place, victims may not recognize misconduct as sexual harassment, especially initially. The mass media create a cultural atmosphere not conducive to recognizing and reporting sexual harassment. One content analysis of prime time network shows found $84 \%$ featured at least one incident of sexual harassment, averaging 3.4 incidents per episode. Despite their pervasiveness, these incidents were not portrayed as serious; rather, they were treated humorously or trivialized. Victims rarely showed realistic emotions like anger or fear, and usually were pictured as not suffering any harm. Instead, victims easily handled the harassment, often with a smart retort. So popular culture treats sexual harassment as both highly visible and yet (realistically) invisible (COCHRAN, 2004), contributing to its "erasure" through non-recognition (DOUGHERTY, 2006, p. 496).

Dominant ideologies also inhibit reporting. The so-called "just world syndrome", which maintains that the world is basically fair ("what is, is good"), works against recognizing harassment. A peculiarly American ideology of "exit", which is simply a rarefied version of the Lockean liberal individual that permeates political and personal thinking, 
sees life through a "lens of choice", holding that individuals have options and thus are responsible for all their actions. The exit ideology tends to reinforce feelings of self-blame for harassment; at the very least, it privileges self-help as the proper method to cure the problem, ignoring the constraints inherent in the situation. Beyond self-blame, these pervasive ideologies cause others to lack sympathy with victims. Emotions interact with ideologies. Victims often experience fear, of physical retaliation if they report, of not being believed, of being labeled as trouble-makers or not team players, of themselves being blamed for the conduct, of the embarrassment and loss of privacy complaints inevitably bring, and of negative consequences for their families. Naturally, fear of career harm looms large in non-reporting, with $3 / 4$ of victims saying they fear retaliation, an imminently realistically fear. Two studies found that almost a quarter of victims who complained were fired; another study discovered that almost one half of complainants were fired and another $25 \%$ quit because of fear or frustration; while another study found that $42 \%$ of complaints eventually relinquished their positions because of retaliation or failure to stop the harassment (COCHRAN, 2004, p. 187). Overall, while fears that complaining will lead to career suicide may be exaggerated, $57 \%$ of complainants reported career harms of some form.

Other reasons for non-reporting include a sense of futility. One survey found that only $20 \%$ of women who complained felt their cases were deal with justly by their employer (versus $70 \%$ of HR managers who believe sexual harassment cases are handled justly). An early (1988) study of employer responses found that $80 \%$ of harassers received only verbal or written reprimands, while a mere $6 \%$ were given transfers, suspensions, probation or demotions (although 2 in 10 were eventually discharged). Many employees perceive a "double discourse" about the issue in their workplaces - a strict official policy against harassment mixed with subtle signals and scuttlebutt that says otherwise. Nor are lawsuits alleging sexual harassment easy to win. Fifty-four percent are dismissed before reaching trial based on pre-trial motions. If tried, plaintiffs fare better before juries (winning 39\% of the cases) than before judges (winning only $20 \%$ of bench 
trials). Appeals are even less favorable to plaintiffs. Losing defendants succeed in getting verdicts reversed in $44 \%$ of their appeals, but unsuccessful plaintiffs win reversals in only $6 \%$. Many observers have noted that federal judges are hostile to employment suits; they seem preoccupied with the danger of such suits flooding the courts, and they may be particularly adverse to sexual harassment claims that typically are characterized by a "he said/she said" posture. Further, judges display little empathy with sexual harassment victims. Most federal judges are male, white, Republican (at least at this time), older, richer, highly educated professionals who have more experience as employers than as employees. "Judges are elitists, individualists, overachievers, meritocrats, and fierce competitors" (SCHATZKI apud COMPA, 2002, p. 116). As a group, they have little understanding of labor issues generally, and in particular find it hard to empathize with women who do not assert their rights forcefully if harassed.

The vastly different contexts, however, between the setting in which harassment occurs and the trial venue present striking discontinuities and require precisely the sort of empathy that many judges lack. At trial, reporting harassment appears imminently reasonable. The plaintiff is protected and supported by the court personnel and her attorney. In retrospect, the conduct involved and the consequences of reporting are clear, and even if negative, she has navigated all obstacles to reach trial. None of this is present at the time and place of the harassment's occurrence. The victim, generally alone and without support or resources, must make judgments about the conduct and prospectively try to predict the consequences of reporting, often under duress of extreme pressure from powerful harassers. In court, the plaintiff appears strong, clam, autonomous, a "rational actor". But psychological research has shown that the primary appraisal of behavior focuses largely on emotional reactions. The typical emotional sequence experienced by targets of sexual harassment includes 1) confusion/self-blame; 2) fear/anxiety; 3) depression/anger; and 4) disillusionment (WRIGHT; FITZGERALD, 2007, p. 74-78). In that situation, lack of complaint should not be equated with lack of response. In fact, not resorting to formal procedures might appear reasonable, and 
studies in fact find that alternative responses are much more frequently chosen. Between a quarter to a half of all victims "ignore" the problem, but that term may obscure various responses, such as a disposition to temporize in hopes that the harassment will dissipate, actively assess various response options, or simply avoid the harasser. Another $25 \%$ respond "mildly" by resorting to such tactics as treating the harassment as a joke, answer with humor or diversionary retorts, or posing polite requests to stop (one study found that $40 \%$ explicitly ask harassers to stop). Between $10 \%$ and $25 \%$ take more drastic steps to avoid the harasser, such as requesting transfers or quitting. Very few actually file formal charges: $10 \%$ with the employer, $2 \%$ with the EEOC, and $1 \%$ of chargers eventually go to court (BEINER, 2000, p. 54-57).

Judges, however, are unlikely to view anything other than lodging formal complaints as reasonable. This failure of empathy with victims is partly because judges tend to view work discrimination through a lens of "insular individualism", described by Tristin Green (2008, p. 375-382) as "the belief that discrimination can be reduced to the action of an individual decision maker (or group of decision-makers) isolated from the work environment and the employer". Insular individualism assumes a principal-agent model of organizational misconduct, viewing it as "primarily a problem of single, independent agents who disregard the preferences of the employer". This perspective, however, "underestimates the influence of context on individual decision-making" and "ignores the employer's role in creating that context". Insular individualism results in courts adopting legal rules that narrow the scope of evidence admissible to prove discrimination, constrict statute of limitations requirements, and weaken doctrines of employer liability. After all, "if employers are innocent bystanders, then we need expect very little of them in the way of efforts to change their own structures and cultures to minimize discrimination" (GREEN, 2008, p. 371-371).

In sum, an interesting dialectic appears to be at work in the common-law process of interpreting legislation or elaborating court-created rules governing sexual harassment: courts first proclaim broadened rights 
and heightened protection, even encouraging employers to act preemptively to prevent sexual harassment. Over time, however, courts strike a contradictory posture by undermining important details of effective rights-claiming system on both front end (making claims) and back end (protection against retaliation against claimants) (BRAKE; GROSSMAN, 2008 , p. 3). This pattern is not unique to sexual harassment or discrimination law. A similar path was followed in labor law, characterized as "judicial deradicalization" of the National Labor Relations Act by Karl Klare (1998). Civil rights law has suffered a similar retrenchment, with the Supreme Court's latest ruling resembling Plessy v. Ferguson (1896) more than Brown (1954) (PARENTS INVOLVED, 2006; ROSENBERG, 1991). Alan Freedman (1991) criticizes courts for assuming a "perpetrator's perspective" rather than a "victim's perspective". The point of civil rights legislation from the point of view of discrimination victims is to produce effective change, requiring a framework rooted in concrete historical experience and endorsing rules aimed at structural discrimination rather than timeless, abstract norms. The perpetrator's perspective, by contrast, emphasizes eradicating the misconduct of wrongdoers rather than systemic social transformation. It focuses on intentional acts of individuals rather than social conditions and shows a central concern with establishing fault. In the process, it places the blame on particular perpetrators as well as the burden for remedying bad behavior, implicitly excusing employers and other powerful social entities from responsibility. The goal is compensation for individual victims rather than the solution of social problems ${ }^{7}$. The pattern resembles a broader phenomenon labeled by Murray Edelman (1964) as "the symbolic uses of politics". Edelman argued that symbolic politics served to keep the public quiescent by creating

7 Sexual harassment law has, from its origins, exhibited strong indications of the perpetrator's perspective. Meritor's conclusions that harassing conduct be severe or pervasive, that it be unwelcome, and that dress and sexual fantasy not be a priori inadmissible all reflect an implicit concern that the guilt of accused perpetrators be firmly established. Despite the seemingly progressive Ellerth/Faragher rules that shift the burden to employers to escape liability, in practice courts allow the reasonableness of victims to displace a focus on employer responsibility. 
the illusion that government was busily endeavoring to cure social problems while actually only taking token steps to remedy or improve the situation. Ultimately, this pattern of contained social change may simply reflect the limits of a demobilized democracy in which elites, including prominently the courts, make policy in the absence of real constraints of a public mobilized by meaningful electoral participation or popular movements (CRENSON; GINSBERG, 2000).

\section{Sexual harassment law in Brazil}

A comparison of sexual harassment in Brazil and that countries rights-claiming system has potential to help identify legal designs that might improve the effectiveness of law in prohibiting harassing behavior. Unfortunately, as is true for the U.S., reliable data are typically lacking on almost all aspects of this social problem. Even the incidence of sexual harassment in Brazil and other countries is subject to widely varying estimates. Merkin (2008, p. 282) found that $4.7 \%$ of employees in Brazil experienced sexual harassment, compared to $8.7 \%$ in Chile and $3.5 \%$ in Argentina. A 1995 survey of Brazilian women in 12 major cities found that 52\% had experience sexual harassment (PAMPLONA, 2005, p. 5-6). Twenty-six percent of a sample of Brazilian domestic workers reported that they had been sexually harassed in the last year. Although domestics are undoubtedly much more vulnerable to sexual harassment than the average employee, a survey of secretaries in Sao Paulo found that $24 \%$ reported sexual harassment (BOSCO, 2001, p. 9). These numbers compare to $44 \%$ of U.S. women reporting sexual harassment (a median derived from 18 surveys; reported frequency of sexual harassment ranged from $28 \%$ to $90 \%$ in a 1999 overview of studies); 17\% in Sweden; 50\% to $90 \%$ of working women in Britain; $30 \%$ to $34 \%$ in Belgium, $34 \%$ in Finland; 21\% in France; 36\% in the former Soviet Union; 50\% to $60 \%$ in the Netherlands, $63 \%$ in Norway, $70 \%$ to $75 \%$ in Germany, and $80 \%$ to $90 \%$ in Spain (COCHRAN, 2004, p. 30). It is, however, impossible to 
disentangle the effects of different definitions and methods employed in these studies from real differences in frequency. Whether valid or not, the estimate of Almeida Teles (2006, p. 487) that a woman is sexually harassed in Brazil every 9 seconds indicates that the problem is significant in that country as well.

Obviously, socio-cultural influences are important in explaining cross-national differences in both the phenomenon of sexual harassment as well as individual and social responses and legal remedies. One measure with some potential for capturing relevant cultural differences is Hofstede's typology of cultural dimensions. The masculine/feminine dimension contrasts values such as power, success, money, assertiveness, and competition with emphasis on relationships, feelings, and the preservation of human dignity. Individualism versus collectivism could influence both the perception of and responses to sexual harassment. Power distance measures how likely societies are to tolerate inequality in power and authority, while uncertainty avoidance taps concerns for security and need for consensus. Long-term orientation values thrift and perserverance rather than tradition, social obligation, and face saving (FIEDLER; BLANCO, 2006, p. 276-277; ZIMBROFF, 2007, p. 1326-1327). Historical and social structures, although perhaps less proximate to the problem, are also relevant. For example, levels of social inequality are unusually high in Brazil, although the United States also ranks high on measures of socio-economic inequality. Brazil and the U.S. also share histories of colonization, slavery, and immigration, resulting not only in great social inequality but also in rich ethnic and racial diversity, although the particularities of these common traits vary significantly (HOLANDA, 1936; MOOG, 1956; TELES, 2006). Variations in national media could also affect the social climate in ways impinging on the frequency, perception, and responses to sexual harassment. In Brazil, as in France, nationalist news coverage tends to fortify an image of sexual harassment concerns as a cultural imposition reflecting obsessions of an overbearing, and extremely Puritanical, U.S. (SAGUAY, 2003). Organized groups, especially women's movement, can have significant influence on culture, 
independent of media influence. Brazil's organized feminism is strongest in Latin America (FIEDLER; BLANCO, 2006, p. 281), although the U.S. women's movement has played a longer and more prominent social role, despite recent backlash (EVANS, 1997).

Of more immediate interest here is the influence of legal systems and rights-claiming regimes on responding to and remedying sexual harassment. Here, stark differences characterize the Brazilian and U.S. legal systems, offering interesting "laboratories" in which to test the impact of differing legal designs on common social problems. Most saliently, Brazil is a civil law rather than common law system (MERRYMAN, 1985), which affects many aspects of its system for regulating a social problem such as sexual harassment. Although judges in both systems pay lip service to their limited role as interpreters rather than legislators of laws, civil law judges are much more restrained in their willingness to stray from the text or fill in gaps in interpreting laws. Civil law judges enjoy much greater independence in their jobs as interpreters, however, because judicial authority is less hierarchically structured and civil law judges rely less on precedent, the method par excellence in common law judging. Judging in civil law countries such as Brazil is much more of a professional career, typically entered into as a young, recently graduated lawyer on the basis of merit, established by a course of tests, and pursued during a lifetime, rather than a political plum often serving to reward powerful and partisan players, as it is in the U.S. The result of this difference is that judges in Brazil tend to be more professional and less politically powerful or engaged, more academically talented and involved with scholarship, more diverse in their background, and more insulated from public and political pressures. In particular, Brazil has many more women judges, which could affect legal approaches to sexual harassment

8 The increasing use by Brazilian courts of súmulas vinculantes, in effect, statements of biding precedent, will limit the independence and discretion of Brazilian judges a higher courts increasingly make rulings or announce other guidance that serve to guide rulings in similar cases in the future (TAYLOR, M. M. Judging policy: courts and policy reform in democratic Brazil. Stanford: Stanford University Press, 2008). 
to the extent that gender differences shape perceptions and analysis of this problem. Despite these momentous differences between civil and common law systems, Taylor (2008) shows that judges in Brazil play increasingly prominent role in policy-making process. Perhaps not coincidentally, the treatment of sexual harassment in Brazilian employment law displays an eerie similarity to the manner in which sexual harassment came to be prohibited by Title VII in the U.S.

Another salient difference between the U.S. and Brazil is the specialized system devoted to employment law in Brazil. Instead of being merely a particular area of civil law, as in the U.S., Brazilian employment law (Direito do Trabalho) has its own code (CLT) and specialized set of courts (Justiça do Trabalho). Originating in the Vargas regime of the 1930s and strongly marked by corporatism, the system has exhibited a remarkable durability across different political regimes, both dictatorial and democratic. In addition to organizing and regulating a system of unions and associations for both employees and employers, the CLT codifies aspects of individual employment, meaning that employee rights in Brazil are primarily legislated rather than negotiated on an individual or collective basis (FRENCH, 2004). Three tiers of courts (District Courts Varas), regional appeals courts (Tribunais Regionais do Trabalho-TRTs), and a Supreme Labor Court (Tribunal Superior do Trabalho - TST) have jurisdiction over laws governing the employment relationship, and since constitutional amendment 45 passed in 2004, over conflicts arising from work relations more generally.

Despite the existence of this specialized employment law system, sexual harassment in Brazilian law was initially treated as a criminal violation. A law enacted May 15, 2001 (Lei n. 10.224/01) added sexual harassment to the Brazilian penal code (article 216-A) in the chapter on crimes against sexual liberty. This provision makes it a crime to "constrain anyone, with the motive of obtaining sexual advantage or favors, taking advantage of the perpetrator's condition of hierarchical superiority or ascendancy inherent in the exercise of his job, responsibility, or function". The penalty specified was incarceration for one to two years (BOSCO, 2001). 
As a rights-claiming system, using the penal code to prohibit sexual harassment has a number of drawbacks. First, the burden is on victims to file a charge and prove that they suffered the harassment (Pinheiro Coutinho). Also, the procedural requirements of criminal trials are too stringent, including narrower admissibility of evidence and the high standard of proof beyond a reasonable doubt, making conviction difficult. Moreover, the punishment, incarceration, may be too heavy for many instances of sexual harassment, leading to hesitancy to report and reluctance to convict. The emphasis is on punishing the perpetrator to the neglect of compensating the victim. More problematic from a social perspective, the punishment is meted out only to perpetrators, failing to hold employers accountable for the misconduct of their employees. Only quid pro quo sexual harassment is prohibited; hostile environment harassment is not mentioned. Although the statute is aimed at abuse of power and is pegged to hierarchical inequalities, there is no recognition of gender inequality and the role that sexual harassment plays in perpetuating that gap.

These deficiencies did not go unnoticed ${ }^{9}$, and in a movement that appears to partake more of common law legal development through case law than of civil law court's strict deference to legislatures, the Brazilian employment courts have begun to interpret the broad illegal employment abuse of moral wrong (dano moral) or moral harassment (assedio moral) as including the narrower specific abuse of sexual harassment (assedio sexual). Mascaro Nascimento (2004) defines moral harassment, or mobbing, bullying, or psychological terrorism, as "abusive conduct of a psychological nature that attacks the physical dignity, in repeated and prolonged form, and that exposes the worker to humiliating and embarrassing situations, capable of causing offense to the personality, dignity, or psychic integrity, and which has the effect of excluding from the position of employment our deteriorating the work environment during work hours or

9 One problem potentially is that the penal statute is based on a view of power that Dougherty (2006) would suggest is a masculinist conception of power. 
in the exercise of its functions" ${ }^{10}$. Although courts have extended this offense to cover sexual harassment, they are not without statutory basis. The Federal Constitution of 1988 recognizes as one of the fundamental principles of the Republic the dignity of the human person (article 1, III), and article 5, $\mathrm{X}$ assures Brazilians' right of protected intimacy, private life, honor and personal image and a right to indemnification for moral or material harm done by their violation. Sexual harassment can also be seen as a violation of sexual liberty, which the Constitution arguably protects in its guarantee of intimacy and private life in article V, X (RAMOS, p. 19). The CLT article 483, $\mathrm{d}$ and e, authorizes employees to consider the employment contract rescinded and to sue for indemnification if the employer does not fulfill the obligations of the contract (and every employment contract presupposes the employer's obligation to maintain a safe and sound workplace) or if the employer harms the honor or good reputation of the employee.

Bills have been proposed, but vetoed, that would have prohibited sexual harassment outside the workplace, but for now, the only nonpenal prohibition on sexual harassment resides in the employment code (BOSCO, 2001, p. 15). Employment jurisprudence conceives of sexual harassment as a species of moral harassment, an offence with the following elements: 1) a psychological nature, consisting of words, acts, gestures, writings capable of causing offense to the personality, dignity, or physical or psychological integrity of a person, puts their job at risk, or degrades the climate of work; 2) conduct that is repeated, prolonged (along the order of once a week for six months, although as a rule the period must last from one to three years), or humiliating (and a single act can be illegal if sufficiently offensive; 3) with an objective to exclude the victim, retaining a discriminatory aspect in motivation; and 4) the requirement

10 Mascaro Nascimento (2004) cites a 2001 report that 42\% of employees in Sao Paulo had experienced humiliation at work; there was a vast difference in the rate for women (65\%) versus men (29\%). A 2006 study found that $42 \%$ of workers were victims of moral harm (ASSOCIAÇÃO NACIONAL DOS PROCURADORES DO TRABALHO. Assédio moral atinge 42\% dos trabalhadores. Available at: <http://www.anpt.org.br>. Access on: 29 May 2006).

Rev. Direito Econ. Socioambiental, Curitiba, v. 3, n. 2, p. 401-446, jul./dez. 2012 
of psychological or emotional harm, although Mascaro Nascimento (2004, p. 4-8) differentiates between assedio moral, which requires proof of emotional or psychological harm and dano moral, which could result from a single incident and lack such proof).

The TST uses the definition of sexual harassment developed by the International Labor Organization: acts, insinuations, forced physical contacts, impertinent invitations, as long as they present one of the following characteristics: a) being an explicit condition of maintaining employment; $b$ ) influences promotions of the harassed; c) harms the professional income, humiliates, insults, or intimidates the victim. Pamplona (2005, p. 4) identifies the following elements necessary to constitute sexual harassment: 1) subjects - perpetrator and target; 2) conduct of a sexual nature; 3) rejection of the conduct by the target; and 4) repetition of the conduct by the perpetrator. The subjects can be male or female, same or different sexes, at any level of the organizational hierarchy. The conduct can take diverse forms and depends on context ${ }^{11}$. The conduct must be repelled explicitly by the target, or at least proved to be conduct outside the social norm. Although the behavior must be repeated, Pamplona notes that in other countries, one instance of physical contact of intense and unacceptable intimacy suffices to be illegal and raises the possibility that an exception to the repetition requirement in Brazil is conceivable.

Two types of sexual harassment, as well as moral harassment, are recognized (ALVES, 2003, p. 4; NASCIMENTO, 2004, p. 3-4). Sexual harassment "por chantagem" (by blackmail) involves the illegitimate use of hierarchical power to pressure victims at risk of employment or benefits for sexual favors. It corresponds to quid pro quo in the U.S. and is a crime in Brazil. Sexual harassment "por intimidação" (by intimidation) is constituted by solicitations for sex or other verbal or physical abuses that have the effect of harming victims' working conditions or creating

11 Pamplona (2005, p. 5) uses the example of greeting with kisses, which may vary in Brazil from one, two, or three kisses, depending on the region. Informal kisses as a greeting at work would generally be seen as improper in the U.S. 
an offensive, hostile, intimidating, or abusive working situation, corresponding to hostile environment sexual harassment in the U.S. While the former type is a species of vertical harassment, necessarily "descendente" (descending, that is, practiced by those higher in the organization), the latter can be practiced by colleagues of the same level or even "ascendente" (ascending: employees harassing supervisors or those higher in the organization) (MOLON, 2005, p. 8; NASCIMENTO, 2004, p. 3-4). Harassment by intimidation is not covered by the penal code, but can provide a cause of action in employment law.

Alves (2003, p. 6-7) points out several peculiar procedural issues arising in sexual harassment litigation in labor courts. Although labor cases normally are tried with total transparency in public processes, courts may impose secrecy to protect sexual harassment victims. Proof, often lacking direct witnesses for an offense generally practiced in private, can be quite diverse, e.g., emails, notes, ripped clothing, etc., and can be circumstantial. The burden of proof is complex: varying slightly from ordinary civil litigation, in labor courts the burden is on the party who makes any particular allegation to prove it (MOLON, 2005, p. 25). In sexual harassment cases, if the perpetrator has already been tried and found guilty in a criminal process, plaintiffs are relieved of the burden of proving guilt again in the labor court; they only have to prove the extent of their injuries. Otherwise, plaintiffs bear the burden of proof, although judges can reverse this burden, requiring the employer to prove that its workplace was healthy and that it was watchful of good relations in the workplace, with the goal of overcoming the presumption that the harassment occurred (SAKO, 2008, p. 186). In a final twist, if the employer is found liable for the harassment, it may in turn sue the actual perpetrator(s) to recover any damages for which it has been held liable.

Beyond possible criminal prosecution for quid pro quo harassment, a finding of sexual harassment has several consequences perpetrators. Perpetrators can be fired with just cause under article 482 (b, c) of the CLT, denying them benefits otherwise due them under Brazil's labor code (BOSCO, 2001, p. 20). If the harasser is the employer or a supervisor, 
the victim may claim indirect rescission of the employment contract (in effect a claim for constructive discharge). In either case, the harasser could be liable to indemnify the victim for moral harm, given the violation of a right to intimacy constitutionally guaranteed (article 5, X). For victims, harassment invokes a right to transfer to another sector or locale of the company. Harassed victims may also quit and claim rescission of the contract (constructive discharge, entitling employees to certain rights for severance benefits under the $C L T$ ). And victims may sue harassers for damages under the Constitution or employers for damages under the CLT or for breach of the employment contract (ALVES, 2003, p. 5-6).

Employer liability for moral harm is grounded in the Civil Code and the CLT. Molon (2005, p. 10-12) denotes an illicit act, fault or fraud, causal connection, and harm as the elements of liability, although he notes that risk alone, without blame in the narrow sense, is sufficient for objective liability (strict liability) instead of subjective liability (for intentional or negligent wrongs) since liability is grounded more in the concept of harm than of blame (9). Section 1.521, III, of the Civil Code and Edict (súmula) 341 of the Supreme Court (Supremo Tribunal Federal) lodges responsibility in employers for the acts of their agents (prepostos) (respondeat superior). Article 483, 1 of the CLT makes employers liable for the acts of their agents. Goretti (2001, p. 19) argues that employers' objective and subsidiary (strict and vicarious) liability can grounded in article 2 of the CLT, which places both the responsibility and risk of the management of the business on the employer, including the obligation to watch over not only the technical aspects but also the good order of the enterprise. This provision means that employers could be held liable for harassment by co-workers or even by clients or suppliers, as long as the harassment occurs in their workplaces (SAKO, 2008, p. 186). Damages for moral harm are "make whole", under the principal that indemnification should make full restitution possible (BOSCO, 2001, p. 20). The employer is also liable for indemnification for contract rescission (severance benefits) under article 483 of the CLT, with damages spelled out in the employment code. Liability under the labor code falls directly on the employer, not 
the harasser, although the employer may in turn sue the harasser in the labor courts, authorized by article 114 of the Constitution (ALVES, 2003, p. 4) and Edit/Sumula 736 of the STF (MOLON, 2005, p. 20), to recoup damages assessed (SAKO, 2008, p. 186). Concerns about possible liability is motivating many Brazilian employers to institute policies against harassment and incorporate them into their employment contracts making employees co-responsible to reimburse any damages paid by the company because by that employee's harassing misconduct, as well as to undertake campaigns against harassment (BOSCO, 2001, p. 20).

Many characteristics of the Brazilian labor law system are userfriendly and should facilitate rights-claiming. The overarching principles that orient the administration of justice through the system are aimed at protecting workers and recognizing the imbalance of power between employers and employees (principally the hipossuficiência, or dependency, of the latter). The system is designed to be accessible; with minimal court costs; the ability to sue without using a lawyer; an informal process relying on oral as much as written transactions; active roles of the judges who, though formally committed to neutrality, seek to do justice as they discover it; the professionalism (appointments based on merit, independently established through tests) and demographic diversity (compared to U.S. federal judges) of the labor judiciary; the aid of procuradores do trabalho (labor prosecutors), independent public officials who prosecute labor law violations and aid parties and the courts in remedying violations; the rapidity of decision-making (with several procedures often compressed into one step); and an imperative to settle cases informally, ranging from the requirement to use Councils of Conciliation before filing suit to the active urging of judges who even craft settlement proposals during audiences. Although awards are small in comparison with potential awards in U.S. civil courts, the ease of use of the courts make them available for disputes of a less egregious nature.

Problems with using Brazilian employment law as an enforcement mechanism against sexual harassment are nonetheless numerous, beginning with the failure of about one half of Brazilian workers to 
secure employment in the formal sector. Those working in the informal sector have virtually no enforceable rights at work. Enforcement of rights is largely left to workers themselves, who are naturally reluctant to sue their bosses. Some critics charge that worker rights in Brazil have been largely an illusion, at least during certain periods of the country's history. Numerous problems plague the Brazilian labor law system in practice, including the congestion caused by rapidly rising numbers of suits and the resultant delays in rendering decisions and resolving conflicts (TAYLOR, 2008, p. 38-41 $)^{12}$. At the least, employment law is criticized for delivering only "justice at a discount" (FRENCH, 2003) or being merely "justice for the discharged", since employees fear to assert their rights until after they are dismisse.

\section{U.S. and Brazilian sexual harassment rights claiming regimes compared}

Review of empirical comparative studies suggests that cultural values are the primary independent variable used the explain variations between Brazil and the U.S., with the primary dependent variable examined being different definitions and judgments about sexual harassment, rather than responses to it. A study by Gelfand, Fitzgerald,and Drasgow (1995), however, found that a multi-factor measure of sexual harassment worked isomorphically cross-culturally, using samples of Brazilian and American students and working women. The authors found that various harassing behaviors measured by the Sexual Experiences Questionnaire (SEQ) factored into three categories: sexual coercion, unwanted sexual attention, and gender harassment. They estimated the prevalence of these types of sexual harassing behaviors to be $50 \%$ plus for gender harassment, 2- to $25 \%$ for unwanted sexual attention, which together correspond to

12 Part of the problem is the accessibility of appeals and the lack of tight precedent in the civil law system. Brazil, however, is increasingly categorized as a "hybrid" rather than pure civil law system, as evidenced by the recent adoption of the device of súmula vinculante (binding precedent) (TAYLOR, 2008, p. 29). 
the legal category of hostile environment harassment, and approximately $5 \%$ to $10 \%$ for sexual coercion, roughly comparable to legally prohibited quid pro quo harassment (p. 168).

Souza, Solberg, and Cerqueira Elder (2007) investigated different perceptions of sexual harassment in simulated same-sex (woman to woman, varying between heterosexual and homosexual) settings. Assessing Brazil to be more collectivist and masculinist than the U.S. on Hofstede's (1991, p. 465-467) dimensions of culture, their findings did not conform neatly to the expectations that individualist and feminist cultures would be more assertive of rights against sexual harassment. They discovered that Brazilians were more likely to define behaviors as sexual harassment, more likely to recommend investigating, and no less likely to recommend punishing it.

Souza, Pryor, and Hutz (1998) also tested U.S.-Brazilian differences in judging punishments deserved for sexual harassment charges. While previous research had revealed no differences in actually experiencing sexually harassing behaviors (GELFAND; FITZGERALD; DRASGOW, 1995), Brazilians have been show to perceive these behaviors less as harassing and more as innocent flirting (SOUZA; PRYOR, 1998, p. 915-922). Men and Brazilian respondents were less likely to recommend punishment in reaction to scenarios depicting harassment, although Brazilians judgments were more punitive when a discriminatory element was present.

As far as reporting, while there are no direct cross-cultural comparisons of the U.S. and Brazil, studies of Brazilian non-reporting find a pattern not dissimilar to the U.S. Asked about reactions to crude behavior by the employer, $77 \%$ of Brazilian workers responded that they would do nothing (with twice as many women saying this as men), while $8 \%$ said they would quit and $13 \%$ asserted that they would respond in kind (BOSCO, 2001, p. 8). Reasons given for non-reporting sound familiar: fear of the employer's power, specifically power to discharge, demote, transfer, or deny letters of reference; fear of ridicule; difficulties articulating the charges; and lack of faith that appeals would lead to effective resolution of the problem (BOSCO, 2001, p. 9). These fears seem well-grounded. 
Souza and Cerqueira (2008, p. 10) found that $25 \%$ of Brazilian domestics had been sexually harassed in the previous year, most frequently by sexual coercion, next by unwanted attention, and lastly by sexual hostility. These women had no trouble recognizing this conduct as harassment (69\% so labeled the behavior), and $92 \%$ claimed to be familiar with the legal definition of harassment. Approximately $62 \%$ asked the perpetrator to stop, but of these, $83 \%$ were "revictimized" by some form of retaliation. A study by a secretaries union found that $59 \%$ of harassers were supervisors, and that $14.3 \%$ of women who refused advances suffered reprisals such as dismissal, loss of promotions, transfer, or hostile environment (2008, p. 9). Brazilian television reinforces this reality by reporting cases of women suffering dismissal as retaliation for complaining about sexual harassment, making other women afraid to corroborate their charges for fear of similar reprisals (SOUZA; PRYOR, 1998, p. 923). A recent study of doctors accused of sexual harassment found that only $4.2 \%$ of the accused were found guilty, and over half the cases never even reached judgment (ROMERO, 2005). Bosco (2001, p. 2) affirms that Brazilian victims of sexual harassment rarely resort to the courts, and that those who do lose "in the overwhelming majority of cases" (2). Much behavior that might be considered sexual harassment elsewhere is dismissed as simply gallantries, flirtation, innocent games or jokes, or tokens of appreciation (8). Leading jurists have opposed legitimating sexual harassment as a cause of legal action, asserting that other prohibitions provide adequate protection (8) or expressing concern about over-sensitive victims (the egg-shell plaintiff problem) or simply denouncing the whole matter as "idiocies and imbecilities typical of some North Americans" (sometimes reinforcing this position by citing well-known "excesses" of U.S. sexual harassment law such as the suspension of elementary school student Jonathan Prevette for kissing a classmate on the cheek) (BOSCO, 2001, p. 12).

Reviewing both the legal and empirical literature on legal systems and reporting suggests several preliminary hypotheses. First, we expect that the importance of cultural as opposed to legal factors in influencing reporting rates will vary in different countries (FIEDLER; 
BLANCO, p. 278). Second, the conventional view of Brazilian and U.S. cultures on Hodstede's cultural dimensions (collectivism, masculinity, power differentials, uncertainty avoidance) suggests that reporting rates should be lower in Brazil, although intuition and past research suggest that these cultural measurements are quite blunt and that other factors may have more influence. Third, one such countervailing factor might be Brazil's legal system; its Justiça do Trabalho is likely to prove much more user-friendly to sexual harassment victims than U.S. federal civil courts, and thus to encourage filing complaints. On the other hand, to the extent that Brazil has only recently legally interdicted sexual harassment, and to the extent that treating the offense as a violation of the labor code as well as a criminal offense is even more recent, sexual harassment lacks the long standing civil remedy that it has in the U.S., discouraging reporting. Fifth, given that rights-claiming is sequential (naming, then blaming, and then claiming), it seems possible, even likely, that different cultural factors will influence different stages of the process. For example, masculinity/femininity might have more influence on naming, individualism/ collectivism could be more potent in influencing blaming, and power differentials could be most salient at the claiming stage. Moreover, sixth, it seems likely that cultural factors generally will have more influence at the naming and blaming stage, while formal legal rules and structures will be more influential at the claiming stage. Last, other institutional factors, such as the existence and roles of organized groups such as women's groups, unions, and churches, and the mass media, should also play large roles, both directly and as shapers of culture and law.

\section{Future directions}

Testing these hypotheses will present difficulties beyond the usual challenges of conceptualization and measurement. Sorting out the relative influences of culture and law in a two-country comparison will prove difficult, although fairly sharp regional cultural variations in both 
countries might provide a solution. Trying to explain differences in reporting rates encounters the dilemma that one can never know whether differences in reporting or in underlying rates of occurrence of sexual harassment. One solution would be to measure respondents intended responses to hypothetical instances of harassment, although this presents problems as well, given that research finds expected responses rarely match actual responses in reaction to sexual harassment. Looking at data over time or, better, comparable data on experiences and reactions in the same subjects should help resolve this problem.

Although surveys or experiments would provide the best data to test hypotheses, preliminary analysis could begin with elite interviewing of judges, prosecutors (procuradores), women's groups and human and civil rights activists, and union leaders to tap their experiential knowledge of these issues. Analysis of legal cases in Brazil's Justiça do Trabalho and U.S. federal courts might also present preliminary confirmation of hypotheses and suggest new patterns or explanations for differences. Preliminary pre-testing of surveys could further refine hypotheses. Finally, an examination of the literature on whistle-blowing, a formal complaint process also heavily influenced by legal design, might provide analogous findings applicable to the issue of reporting sexual harassment (LEE; HEILMANN; NEAR, 2004, p. 317) ${ }^{13}$.

An examination of differences in legal fields could lead to suggestions for improved legal designs. Legal rules need to be backed by an effective rights-claiming system if they are to be provide meaningful regulation and protection. The U.S. teaches that doctrinal and procedural

\footnotetext{
${ }^{13}$ A recent overview of whistle blowing finds that $37 \%$ of U.S. employees have observed "serious waste, fraud, or abuse" at work, but that only $42 \%$ blew the whistle, $21 \%$ of these reporting it to an outside authority (ROTHSCHILD, J. Freedom of speech denied, dignity assaulted: what the whistleblowers experience in the U.S. Current Sociology, v. 56, p. 889, 2008). Repercussions of reporting were very often severe. Sixty-nine percent of internal and $84 \%$ of external whistle blowers were fired or forced to retire. The overwhelming majority found themselves rated poorly thereafter, $62 \%$ of internal and $82 \%$ of external whistle blowers were monitored, and similar percentages were isolated at work.
} 
minutia can often undermine broadened rights. Brazil's Justiça do Trabalho offers an example of how a more informal, cheaper, speedier, and userfriendly legal field may provide more effective relief, especially from minor infractions, but enforcement remains the key to making these protections real. Perhaps the lesson that will emerge from this study is that no matter how well-designed the legal system, enforcement must be activated by employees themselves. To bear that burden, organized support in the workplace, not merely in the courthouse, seems necessary.

\section{References}

ALVES, G. A. O assédio sexual na visão do Direito do Trabalho. Jus Navigandi, v. 8, n. 130, p. 97-122, 2003.

ASSOCIACAO NACIONAL DOS PROCURADORES DO TRABALHO. Assédio moral atinge $42 \%$ dos trabalhadores. Available at: <http://www.anpt.org. br>. Access on: 29 May 2006.

BAER, S. Dignity or equalitiy? Responses to workplace harassment in European, German, and U.S. law. In: MACKINNON, C. A.; SIEGEL, R. B. Directions in sexual harassment law. New Haven: Yale University Press, 2003. p. 582-601.

BAKER, C. N. The women's movement against sexual harassment. Cambridge: Cambridge University Press, 2008.

BEINER, T. M. Gender myths v. working realities. New York: New York University Press, 2000.

BERNSTEIN, A. Law, culture, and harassment. Pennsylvania: University of Pennsylvania Law Review, 1997.

BOSCO, M. G. dal. Assédio sexual nas relações de trabalho. 2001. Available at: <http://jus2.uol.com.br/doutrina/texto.asp?id=2430 >. Access on: 16 Dec. 2009.

BOURDIEU, P. Choses dites. Paris: Les Éditions de Minuit, 1987.

Rev. Direito Econ. Socioambiental, Curitiba, v. 3, n. 2, p. 401-446, jul./dez. 2012 
BRAKE, D. L.; GROSSMAN, J. L. The failure of title vii as a rights-claiming system. North Carolina: Law, 2008.

BROWN V. Board of education. 1954. Available at: <http://caselaw.lp.findlaw. com/scripts/getcase.pl?court=us\&vol=347\&invol=483〉. Access on: 28 Dec. 2012.

BROWN, W. The most we can hope for. Human rights and the politics of fatalism. South Atlantic Quarterly, v. 103, n. 2/3, p. 451-463, 2004.

BURLINGTON NORTHERN \& SANTA FE RAILWAY COMPANY; PETITIONER, V.; WHITE, S. Supreme court of the United States. 2006. Available at: <http:// www.legalmomentum.org/legal-knowledge/legal-cases/employment-cases/burlington-opinion.pdf>. Access o'n: 28 Dec. 2012.

CHINKIN, C. Sexual harassment: an international human rights perspective. In: MACKINNON, C. A.; SIEGEL, R. B. Directions in sexual harassment law. New Haven: Yale University Press, 2003. p. 655-671.

COCHRAN, A. B. III. Sexual harassment and the law: the mechelle vinson case. Lawrence: University Press of Kansas, 2004.

COMPA, L. Author's rely to wheeler-getman-brody papers. British Journal of Industrial Relations, v. 40, p. 114-121, 2002.

CONSOLIDAÇÃO das Leis do Trabalho - CLT. Edited by Amando Casimiro Costa, Irany Ferrari and Melchiades Rodrigues Martins. São Paulo: Editora LTr, 2007.

CRENSON, M. A.; GINSBERG, B. Downsizing democracy: how America sidelined its citizens and privatized its public. Baltimore: Johns Hopkins University Press, 2002.

DOUGHERTY, D. S. Gendered constructions of power during discourse about sexual harassemnt: negotiating competing meanings. Sex Roles, v. 54, p. 495507, 2006.

ELLISON, K. V.; BRADY, N. F. United States Court of Appeals, Ninth Circuit. 1991. Available at: <http://openjurist.org/924/f2d/872/ellison-v-fbrady>. Access on: 29 Dec. 2012. 
EVANS, S. Born for liberty: a history of women in America. New York: Simon and Schuster, 1997.

FIEDLER, A. M.; BLANCO, R. I. The challenge of varying perceptions of sexual harassment: an international study. Journal of Behavioral and Applied Management, v. 7, n. 3, p. 274-292, 2006.

FREEMAN, A. anti-discrimination law. In: KAIRYS, D. The politics of law. New York: Pantheon Books, 1990. p. 1407-1441.

FRENCH, J. Drowning in laws. Chapel Hill: University of North Carolina Press, 2003.

GELFAND, M. J.; FITZGERAL, L. F.; DRASGOW, F. The structure of sexual harassment: a confirmatory analysis across cultures and settings. Journal of Vocational Behavior, v. 47, p. 14-177, 1995.

GOLDBERG, C. B. The impact of training and conflict avoidance on responses to sexual harassment. Psychology of Women Quarterly, v. 31, p. 62-72, 2007.

GREEN, T. K. Insular individualism: employment discrimination law after ledbetter v. Goodyear. Harvard Civil Rights-Civil Liberties Law Review, v. 43, n. 2, p. 335-384, 2008.

GROSSMAN, J. L. The first bite is free: employer liability for sexual harassment. University of Pitssburgh Law Review, v. 61, p. 671-740, 2000.

HARRIS V. Forklift Systems, Inc. (1993) 510 U.S. 17. Available at: <http:// www.law.cornell.edu/supct/html/92-1168.ZO.html>. Access on: 27 Dec. 2012.

HOFSTEDE, G. Cultures and organizations: software of the mind. London: McGraw-Hill, 1991.

HOLANDA, S. B. de. As raízes do Brasil. São Paulo: Companhia das Letras, 1936.

Rev. Direito Econ. Socioambiental, Curitiba, v. 3, n. 2, p. 401-446, jul./dez. 2012 
KAMIR, O. Dignity, respect, and equality in Israel's sexual harassment law. MACKINNON, C. A.; SIEGEL, R. B. Directions in sexual harassment law. New Haven: Yale University Press, 2004. p. 561-581.

KLARE, K. E. Judicial deradicalization of the Wagner Act and the origins of modern legal consciousness, 1937-1941. Minnesota Law Review, v. 62, p. 265-339, 1978.

KOCH Jr., C. H. Envisioning a global legal culture. Michigan Journal of International Law, v. 25, p. 2-76, 2003.

LAW, D. S. Globalization and the future of constitutional rights. Northwestern University Law Review, v. 102, n. 3, p. 1-86, 2008.

LEDBETTER, V. Goodyear tire \& rubber co. 2007. Available at: <http://www. law.cornell.edu/supct/pdf/05-1074P.ZS>. Access on: 27 Dec. 2012.

LEE, J.-Y.; HEILMANN, S. G.; NEAR, J. P. Blowing the whistle on sexual harassment: test of a model of predictors. Human Relations, v. 57, p. 297-322, 2004.

MACKINNON, C. A. The sexual harassment of working women. New Haven: Yale University Press, 1979.

MCCANN, M. Rights at work. Chicago: University of Chicago Press, 1994.

MERITOR SAVINGS BANK, FSB v. Vinson. 477. U.S. 57. 1986. Available at: <http://caselaw.lp.findlaw.com/cgi-bin/getcase.pl?court=us\&vol=477\&invol =57>. Access on: 29 Dec. 2012 .

MERKIN, R. S. Cross-cultural differences in perceiving sexual harassment: democraphic incidence rates of sexual harassment/sexual aggression in Latin America. North American Journal of Psychology, v. 10, n. 2, p. 277-290, 2008.

MERRYMAN, J. H. The civil law tradition. Stanford: Stanford University Press, 1985. 
MOLON, R. C. Assédio moral no ambiente do trabalho e a responsabilidade civil: empregado e empregador. 2005. Available at: <http://jus2.uol.com. br/doutrina/texto.asp?id=6173>. Access on: 16 Dec. 2009.

MOOG, V. Bandeirantes e pioneiros. Rio de Janeiro: Globo, 1956.

NASCIMENTO, S. A. C. M. Moral harassment in the work environment. Jus Navigandi. Available at: <http://www.jus.com.br/doutrina/texto.asp?id=5433>. Access on: 25 Nov. 2004.

NUSSBAUM, M. C. The modesty of Mrs. Bajai: India's problematic route to sexual harassment law. In: MACKINNON, C. A.; SIEGEL, R. B. Directions in sexual harassment law. New Haven: Yale University Press, 2004. p. 633-671.

ONCALE, V. Sundowner Offshore Services, Inc. (1998) 523 U.S. 75. Available at: <http://www.law.cornell.edu/supct/html/96-568.ZO.html〉. Access on: 29 Dec. 2012.

ORIHEULA, S.; MONTJOY, A. The evolution of Latin America's sexual harassment law: a look at mini-skirts and multinationals in Peru. California Western International Law Journal, v. 30, p. 323-344, 2000.

PAMPLONA FILHO, R. Assédio sexual: questões conceituais. Jus Navigandi, v. 9, n. 704, 2005. Available at: <http://jus2.uol.com.br/doutrina/texto.asp?id $=6826>$. Access on: 1 July 2008 .

PARENTS INVOLVED IN COMMUNITY SCHOOLS V. SEATTLE SCHOOL DISTRICT N. 1. 551 U.S. 701, 2006. Available at: <http://supreme.justia.com/ cases/federal/us/551/05-908/>. Access on: 16 July 2012.

PFANNER, E. A fight to protect Americans from British libel law. New York Times, May 25, B3, 2009.

RAMOS, C. M. O direito fundamental à intimidade e à vida privada. Revista de Direito da Unigranrio, v. 1, n. 1, p. 1-30, 2008.

ROMERO, T. Mapa do assédio. 2009. Available at: <http://www.agencia.fapesp. br>. Access on: 26 Apr. 2009.

Rev. Direito Econ. Socioambiental, Curitiba, v. 3, n. 2, p. 401-446, jul./dez. 2012 
ROSENBERG, G. Hollow hope: can courts bring about social change? Chicago: University of Chicago Press, 1991.

ROTHSCHILD, J. Freedom of speech denied, dignity assaulted: what the whistleblowers experience in the US. Current Sociology, v. 56, p. 884-903, 2008.

SAGUAY, A. C. What is sexual harassment: from Capitol Hill to the Sorbonne. Berkeley: University of California Press, 2003.

SAKO, E. S. Ônus da prova nas ações da indenização por atos ilícitos praticados pelo empregador nas relações do emprego ou do trabalho. Revista LTr, v. 72, n. 2, p. 185-186, 2008.

SCHULTZ, V. Reconceptualizing sexual harassment. Yale Law Journal, v. 107, p. 1683-1804, 1998.

SOUZA, E. R. de; PRYOR, J. B. Reactions to sexual harassment charges between North American and Brazilians. Sex Roles, v. 39, n. 11-12, p. 913-928, 1998.

SOUZA, E. R. de; SOLBERG, J.; ELDER, C. A cross-cultural perspective on judgments of woman-to-woman sexual harassment: does sexual orientation matter? Sex Roles, v. 56, p. 457-471, 2007.

STONE, K. van W. Mandatory arbitration of individual employment rights: the yellow dog contract of the 1990s. Denver University Law Review, v. 73, n. 4, p. 1017-1050, 1996.

TAYLOR, M. M. Judging policy: courts and policy reform in democratic Brazil. Stanford: Stanford University Press, 2008.

TELeS, M. A. A. Women's human rights in Brazil. Peace Review, v. 18, p. 485-490, 2006.

TELLES, E. E. Race in another America: the significance of skin color in Brazil. Princeton: Princeton University Press, 2004. 
TSUNODA, U. Sexual harassment in Japan. In: MACKINNON, C. A.; SIEGEL, R. B. Directions in sexual harassment law. New Haven: Yale University Press, 2004. p. 138-154.

WEYLAND, K. Theories of policy diffusion: lessons from Latin American pension reform. World Politics, v. 57, n. 2, p. 262-295, 2005.

WRIGHT, C. V.; FITZGERALD, L. F. Angry and afraid: women's appraisal of sexual harassment during litigation. Psychology of Women Quarterly, v. 31, p. 7384, 2007.

ZIMBROFF, J. Cultural differences in perceptions of and responses to sexual harassment. Duke Journal of Gender Law and Policy, v. 14, p. 1311-1341, 2007.

ZIPPEL, K. Practices of implementation of sexual harassment policies; individual versus collective strategies. Review of Policy Research, v. 20, n. 1, p. 175-198, 2003.

ZIPPEL, K. Transnational advocacy networks and policy cycles in the European Union: the case of sexual harassment. Social Politics, v. 11, n. 1, p. 57-85, 2004.

Received: 05/02/2012

Recebido: 02/05/2012

Approved: 07/12/2012

Aprovado: 12/07/2012

Rev. Direito Econ. Socioambiental, Curitiba, v. 3, n. 2, p. 401-446, jul./dez. 2012 